\title{
Amino acid uptake in chickens subjected to increasing levels of quantitative food restriction
}

\author{
BY R. M. Gous \\ Department of Animal Science and Poultry Science, University of Natal, \\ Pietermaritzburg 3200, South Africa
}

(Received 30 April 1976 - Accepted 4 January 1977)

1. Three groups of cockerels were reared from 3 to 11 weeks of age on increasingly severe quantitative food restriction treatments, resulting in body-weight values of 12,19 and $27 \%$ below that of a control group which was fed $a b l i b$.

2. The rate of uptake of L-arginine, glycine, L-lysine and L-phenylalanine was measured in vitro using intestinal rings, over a $5 \mathrm{~min}$ incubation period.

3. Uptake of L-arginine was significantly increased with increasing degrees of body-weight restriction. This amino acid and L-lysine were the only two to show a significantly enhanced uptake rate as a result of the restriction treatments.

4. No significant differences were noted in the case of glycine or L-phenylalanine uptake following food restriction, indicating a certain selectivity in the alteration of absorption rates following food restriction, when such tests are conducted in vitro.

Various theories have been propounded concerning homoeostatic mechanisms in the animal which are purported to respond to dietary manipulation. Such responses include a decline in absorption rate of an amino acid following hyperaminoacidaemia, induced by feeding a diet containing an excess of that amino acid (Wapnir, Hawkins \& Lifshitz, 1972); and a compensatory mechanism which increases the ability of the small intestine to absorb glucose and L-histidine following varying degrees of dietary restriction (Kershaw, Neame \& Wiseman, 1960).

These homoeostatic mechanisms appear to be more sensitive to the feeding of diets unbalanced with respect to certain amino acids than to the quantitative restriction of growth either by semi-starvation or by intermittent feeding. Thus, reports concerning enhanced transport of amino acids following the feeding of unbalanced diets are generally in agreement (Wapnir et al. 1972; Nakamura, Yasumoto \& Mitsuda, 1972; Wapnir \& Lifshitz, 1974), whereas those concerning the effect of semi-starvation or intermittent feeding on amino acid absorption are often contradictory (Fabry \& Kujalova, 1958; Kujalova \& Fabry, 1960; Preston-Mafham \& Sykes, 1970).

Also, reports vary according to the method of determination of transport rates. Neame \& Wiseman (1959) and Kershaw et al. (1960), using in vivo methods, were among the first to demonstrate an enhanced rate of uptake of both glucose and L-histidine following semistarvation, but in vitro experiments showing that amino acid uptake is enhanced following quantitative food restriction could not be found in the literature.

Because the restricted feeding of pullets during the growing period is now an accepted practice, it is important to understand the effects of such treatments on basic physiological processes such as uptake of amino acid by the intestine. For this reason, such a study was conducted in conjunction with a food restriction experiment in which the growth of pullets was restricted quantitatively (Gous \& Stielau, 1976). In the present experiment the effect of three levels of quantitative food restriction on the rate of uptake of four amino acids was studied, using cockerels as experimental material, assuming the effects of dietary restriction on growth and absorption rate to be similar for both males and females. 


\section{EXPERIMENTAL PROCEDURE}

\section{Experimental birds}

Cockerels of a Leghorn $\times$ Australorp strain were reared from 3 to 11 weeks of age in wire colony cages, six birds per cage. The rearing diet shown in Table 1 was offered. Three replications of four treatments were used, these being: (1) a control treatment, birds being fed ad lib.; (2) a quantitative food restriction treatment designed to produce chickens with a body-weight $10 \%$ below that of birds fed ad lib.; (3) as in (2), but a $20 \%$ body-weight restriction was applied; (4) as in (2), but body-weight was restricted by $30 \%$ below the body-weight of chickens fed ad lib.

In the quantitative restriction treatments, a $2 \mathrm{~d}$ quantity of food was supplied every alternate day in order to reduce variability in body-weight within each treatment. The amount of food supplied on the basis of weekly weight measurements of birds in each treatment, was increased or decreased according to the deviation from the target bodyweight.

\section{Preparation of tissue}

All chickens were fasted for 16 to $20 \mathrm{~h}$ before experimentation but free access to water was allowed during this period. Had the experiment been conducted in vivo it may be argued that acclimatization to this $16-20 \mathrm{~h}$ starvation period may have been possible, if changes in uptake rate are mediated in part by the level of amino acids in the blood (Wapnir et al., 1972). However, such changes in in vitro uptake rates as may be influenced by the dietary treatments are presumed not to be altered appreciably by starvation within the 16-20 h period.

Chickens were killed by neck dislocation, and approximately $40 \mathrm{~cm}$ of intestine immediately anterior to the yolk stalk was excised and rinsed free of digesta with a jet of distilled water. The intestine was then laid on a board covered with filter paper and cut into $1 \mathrm{~cm}$ lengths with the aid of an apparatus containing five razor blades spaced at $1 \mathrm{~cm}$ intervals. Eight segments were allocated in random order to each of four dishes which then facilitated rapid transfer of these segments to the $25 \mathrm{ml}$ Erlenmeyer flasks in which the incubation took place. These flasks were held at $30^{\circ}$ in a shaking water bath, and were continuously aerated with a gas mixture of oxygen and carbon dioxide $(95: 5, \mathrm{v} / \mathrm{v})$.

\section{Conditions of incubation}

The method used in this experiment to determine the rate of uptake of amino acids by isolated segments of chicken intestine was essentially similar to that used by Finch \& Hird (1960). The incubation medium was sampled at various time intervals, and uptake was calculated from the rate of disappearance of the ${ }^{14} \mathrm{C}$-labelled amino acid from this incubation medium.

The tissue was incubated in a medium of Tris buffer (Kimmich, 1070) containing $120 \mathrm{~mm}-\mathrm{NaCl} ; 20 \mathrm{~mm}-\mathrm{Tris}-\mathrm{Cl}(\mathrm{pH} 7 \cdot 4) ; 3 \mathrm{~mm}-\mathrm{K}_{2} \mathrm{HPO}_{4} ; 1 \mathrm{~mm}-\mathrm{MgCl}_{2} ; 1 \mathrm{~mm}-\mathrm{CaCl}_{2}$. The final $\mathrm{pH}$ was $7 \cdot 6$. In addition the medium contained $0.3 \%(\mathrm{w} / \mathrm{v}) \mathrm{D}$-glucose.

The four amino acids, L-arginine, glycine, L-lysine and L-phenylalanine, were made up to a concentration of $40 \mathrm{~mm}$ with respect to the amino acid, to give a final concentration of $2 \mathrm{~mm}$ when this solution was added to the buffer. To each amino acid solution was added the corresponding $\mathrm{U}^{14} \mathrm{C}$-labelled amino acid, but at a negligible concentration compared with that of the ${ }^{12} \mathrm{C}$-labelled amino acid.

To $10 \mathrm{ml}$ of buffer in each flask, $0.5 \mathrm{ml}$ of amino acid solution was added so that, before killing each chicken, four $25 \mathrm{ml}$ flasks each contained one of the four amino acids to be used in the experiment. A duplicate $0.05 \mathrm{ml}$ sample of this medium was removed from each flask in order to calculate the radioactive content at zero time. Incubation was started 
Table 1. Composition $(\mathrm{g} / \mathrm{kg})$ of experimental diet

$\begin{array}{lrlr}\text { Maize } & 351 & \text { Analysis } & \\ \text { Sorghum } & 160 & \text { Crude protein (\%) } & 15.37 \\ \text { Wheat bran } & 116 & \text { ME (MJ } / \mathrm{kg}) & 10.80 \\ \text { Wheat pollard } & 195 & \text { Calcium (\%) } & 0.78 \\ \text { Sunflower meal } & 47 & \text { Phosphorus (available) }(\%) & 0.50 \\ \text { Fish meal } & 60 & \text { Amino acids (calculated) (\%) } & \\ \text { Monocalcium phosphate } & 9 & \text { Lysine } & 0.71 \\ \text { Limestone powder } & 8 & \text { Arginine } & 0.88 \\ \text { Salt } & 3 & \text { Methionine } & 0.30 \\ \text { Molasses } & 50 & \text { Cystine } & 0.55 \\ \text { Vitamins and minerals* } & 1 & \text { Tryptophan } & 0.18\end{array}$

* Provides ( $/ \mathrm{kg}$ diet): $25 \mathrm{mg}$ thiamin, $16 \mathrm{mg}$ riboflavin, $20 \mathrm{mg}$ pantothenic acid, $6 \mathrm{mg}$ pyridoxine, $0.6 \mathrm{mg}$ biotin, $4 \mathrm{mg}$ pteroylmonoglutamic acid, $5 \mathrm{mg}$ menaphthone, $0.02 \mathrm{mg}$ cyanocobalamin, $150 \mathrm{mg}$ nicotinic acid, $250 \mathrm{mg}$ ascorbic acid, $4.2 \mathrm{mg} \alpha$-tocopherol $(25 \%) 150 \mathrm{mg}$ retinol $(1982 \mu \mathrm{g} / \mathrm{g}$ ), $7.2 \mathrm{mg}$ cholecalciferol $(2000 \mu \mathrm{g} / \mathrm{g}), 2 \mathrm{~g}$ choline chloride, $1 \mathrm{~g} \mathrm{KH}_{2} \mathrm{PO}_{4}, 800 \mathrm{mg} \mathrm{NaCl}, 50 \mathrm{mg} \mathrm{Fe}{ }^{2+}, 250 \mathrm{mg} \mathrm{MgSO}$, $20 \mathrm{mg}$ $\mathrm{MnSO}_{4}, 1 \mathrm{mg} \mathrm{KI}, 1 \cdot 28 \mathrm{mg} \mathrm{CuSO}{ }_{4}, 20 \mathrm{mg} \mathrm{ZnCO} 3$.

with a time separation of $15 \mathrm{~s}$ between flasks and the medium was sampled with the aid of a micro-pipette at $1 \mathrm{~min}$ intervals for $5 \mathrm{~min}$.

Radiochemicals were purchased from the Radiochemical Centre, Amersham, Bucks, England. All radioactive amino acids were uniformly-labelled and had a minimum specific activity of $112 \mathrm{mCi} / \mathrm{mmol}$. Other chemicals used were all of analytical grade. Radioactivity in each sample was determined using a Beckman LS200 Liquid Scintillation Spectrophotometer, and $15 \mathrm{ml}$ of a scintillation solution consisting of 2,5-diphenyloxazole (PPO) (10 g), $p$-bis $(O$-methylsyryl)benzene (Bis MSB) $(1 \mathrm{~g})$, toluene (1l) and methanol (1 ll).

\section{RESULTS}

The body-weight of birds at 11 weeks of age is shown in Table 2 . These values are presented as the mean $\pm \mathrm{SE}$ of the mean of sixteen birds per treatment. Body-weight was reduced by $11.8,19.8$ and $27.3 \%$ respectively below that of the control group, these values being close to the intended restriction levels.

The rate of uptake of L-arginine by intestinal preparations of cockerels was significantly increased with increasing degrees of body-weight restriction. This was not the case with the three other amino acids studied (Table 3).

The least-severe restriction treatment resulted in a significant increase in rate of uptake of L-lysine compared with the control treatment. Mean values of uptake rate in the remaining treatments was greater than that of the control rate, but these differences were not significant.

\section{DISCUSSION}

Few critical experiments appear to have been performed in which the effect of food restriction of chickens on intestinal uptake of amino acids has been studied, although a number of reports have been published on such effects following semi-starvation and fasting of rats. One of the first experiments of this kind was conducted by Kershaw et al. (1960), where it was shown that an enhanced rate of disappearance of both glucose and L-histidine from the small intestine of the rat in vivo followed a period of semi-starvation. The work on rats is not entirely comparable with the present work, as the original body weight of the rats was reduced by about $20 \%$ by means of semi-starvation over a period of $9 \mathrm{~d}$, whereas in the present experiment all birds had a greater body-weight at the end of the 8 week restriction period than at the beginning, i.e. growth rate was decreased, but not 
Table 2. Body-weight ( $g$ ) of birds used in the experiment

(Results presented as mean \pm SE of mean for sixteen birds/treatment)

$\begin{array}{lccc}\text { Dietary treatment } & \overbrace{\text { Mean }}^{\text {Mean body- }} & \text { SE } & \begin{array}{c}\text { weight } \\ \text { pody-weight as } \\ \text { percentage of } \\ \text { control }\end{array} \\ \text { Control (ad lib.) } & 923 & 20 & 100 \\ 90 \% \text { of control body-weight } & 813 & 37 & 88 \cdot 2 \\ 80 \% \text { of control body-weight } & 745 & 25 & 80 \cdot 7 \\ 70 \% \text { of control body-weight } & 671 & 24 & 72 \cdot 7\end{array}$

Table 3. Rate of uptake of four amino acids ( $\mu$ mol) by intestinal rings prepared from cockerels subjected to three levels of quantitative food restriction for 8 weeks

(Eight $1 \mathrm{~cm}$ long rings of small intestine incubated with amino acid at $2 \mathrm{~mm}$ concentration, uptake at 5 min taken as a measure of the rate of uptake. Results presented as the mean \pm SE of mean for 16 replications of each treatment)

Restriction treatment

\begin{tabular}{lrrrr}
\cline { 2 - 4 } \multicolumn{1}{c}{$\begin{array}{c}\text { Control } \\
\text { Amino acid }\end{array}$} & $\begin{array}{c}90 \% \\
\text { of control }\end{array}$ & $\begin{array}{c}80 \% \\
\text { of control }\end{array}$ & $\begin{array}{c}70 \% \\
\text { of control }\end{array}$ \\
L-arginine & $9 \cdot 4 \pm 1 \cdot 4^{\mathrm{b}}$ & $9 \cdot 8 \pm 1 \cdot 1^{\mathrm{b}}$ & $12 \cdot 4 \pm 2 \cdot 2^{\mathrm{ab}}$ & $14 \cdot 6 \pm 1 \cdot 8^{\mathrm{a}}$ \\
Glycine & $21 \cdot 3 \pm 1 \cdot 9^{\mathrm{a}}$ & $24 \cdot 2 \pm 2 \cdot 4^{\mathrm{a}}$ & $20 \cdot 2 \pm 2 \cdot 0^{\mathrm{a}}$ & $23 \cdot 7 \pm 1 \cdot 9^{\mathrm{a}}$ \\
L-lysine & $19 \cdot 4 \pm 2 \cdot 1^{\mathrm{b}}$ & $26 \cdot 8 \pm 3 \cdot 0^{\mathrm{a}}$ & $22 \cdot 5 \pm 2 \cdot 9^{\mathrm{ab}}$ & $22 \cdot 1 \pm 2 \cdot 2^{\mathrm{ab}}$ \\
L-phenylalanine & $27 \cdot 5 \pm 2^{\mathrm{a}}$ & $31 \cdot 6 \pm 2 \cdot 9^{\mathrm{a}}$ & $29 \cdot 1 \pm 2 \cdot 7^{\mathrm{a}}$ & $25 \cdot 8 \pm 2 \cdot 6^{\mathrm{a}}$
\end{tabular}

$\mathrm{a}, \mathrm{b}$ Within rows, values with the same superscript do not vary significantly $(P<0 \cdot 05)$. Differences assessed for significance by applying an analysis of variance followed by individual comparisons between the control and restriction treatments by means of $t$-tests (Rayner, 1967).

reversed. Also, experiments of this nature conducted in vivo might be expected to yield results different from those conducted in vitro, if uptake regulatory mechanisms (if any) are situated not in the intestine itself, but in other regions of the body.

No other experiment appears to have demonstrated successfully an enhanced rate of uptake following quantitative food restriction. Kujalova \& Fabry (1960) could find no increase in absorption of amino acid following a 6 week period of intermittent starvation of rats, although these workers later reported an increase in uptake of both glucose and fat following such treatment (Fabry \& Kujalova, 1958). In only one experiment out of three could Preston Mafham and Sykcs (1970) demonstrate a significant increase in the rate of absorption of glucose following a reduction of body-weight of chickens over a period of $5 \mathrm{~d}$. Uptake of L-histidine and glucose following an infection of Eimeria acervulina were, however, significantly reduced in that experiment.

It has been shown that when an amino acid is fed to rats in excess of normal requirement (Wapnir et al. 1972) it causes a decrease in the subsequent absorption rate of that amino acid. Similarly an enhanced absorption of an amino acid has been shown to result following the feeding of a diet low in that amino acid (Nakamura et al. 1972; Wapnir \& Lifshitz, 1974). However, the uptake of amino acids other than those unbalanced in the diet does not appear to be affected by such treatment (Nakamura et al. 1972). These latter workers concluded that the mechanism controlling the rate of uptake of amino acid differs according to the method of growth restriction applied, i.e. the compensatory mechanism that apparently controls rate of uptake of the amino acid used to unbalance a diet is entirely different from that involved in semi-starvation and in protein deficiency. Much of the work that has been reported on the effects of malnourishment on amino acid uptake has been concerned with 
unbalanced amino acid diets, and if the mechanisms controlling uptake under these circumstances do differ from those regulating uptake following quantitative restriction, then this anomaly could account in part for much of the confusion concerning the effects of semistarvation on uptake of amino acids.

In the present experiment, the effect of dietary restriction on rate of uptake of amino acids was not consistent. Only in the cases of L-arginine and L-lysine did quantitative restriction result in a significant increase in rate of uptake of an amino acid compared with the control treatment. Although the rate of uptake of both these amino acids was greater for each level of restriction than was that of the control treatment, the uptake of L-arginine was significantly enhanced only in the most severe restriction treatments, whereas with L-lysine, the only significantly greater rate of uptake, compared with the control, was by intestinal preparations from the least-severely restricted birds.

The fact that the intestinal transport rates of glycine and L-phenylalanine were not altered by any of the restriction treatments confirms the result of Wapnir \& Lifshitz (1974) who noted the same lack of response in the rate of uptake of these two amino acids following the feeding of low protein diets. Their experiment was conducted in vivo. It appears therefore that there is a certain selectivity in the alteration of absorption rates following food restriction. In addition, Hindmarsh, Kilby, Ross \& Wiseman (1967) have shown that intestinal transport activity in response to semi-starvation varies among species of experimental animals, adding further to the difficulty of elucidating the precise mechanisms involved in such homoeostatic processes.

The author is indebted to Mrs Jean Lavers for assistance in the care of the experimental chickens, and to Miss Anthea Pienaar for technical help. Due acknowledgement is made to the Atomic Energy Board and the Department of Agricultural Technical Services for the financial aid which has enabled the above research to be conducted.

\section{REFERENCES}

Fabry, P. \& Kujalova, V. (1958). Naturwissenschaften 45, 373.

Finch, L. R. \& Hird, F. J. R. (1960). Biochim. biophys. Acta 43, 268.

Gous, R. M. \& Stielau, W. J. (1976). Br. Poult. Sci. 17, 487.

Hindmarsh, J. T., Kilby, D., Ross, B. \& Wiseman, G. (1967). J. Physiol. 188, 207.

Kershaw, T. G., Neame, K. D. \& Wiseman, G. (1960). J. Physiol. 152, 182.

Kimmich, G. A. (1970). Biochemistry 9, 3659.

Kujalova, V. \& Fabry, P. (1960). Physiol. bohemoslov. 9, 35.

Nakamura, Y., Yasumoto, K. \& Mitsuda, H. (1972). J. Nutr. 120, 359.

Neame, K. D. \& Wiseman, G. (1959). J. Physiol. 146, $10 P$.

Preston-Mafham, R. A. \& Sykes, A. H. (1970). Parusitol. 61, 417.

Rayner, A. A. (1967). A First Course in Biometry for Agriculture Students, Pietermaritzburg: University of Natal Press.

Wapnir, R. A., Hawkins, R. L. \& Lifshitz, F. (1972). Am. J. Physiol. 223, 788.

Wapnir, R. A. \& Lifshitz, F. (1974). J. Nutr. 104, 843. 